\title{
Reductive Remediation of Pollutants Using Metals
}

\author{
Sumathi Suresh*
}

Centre for Environmental Science and Engineering, Indian Institute of Technology-Bombay, Powai, Mumbai 400 076, India

\begin{abstract}
Metal systems have been extensively used for the abiotic remediation of recalcitrant pollutants. Zero-valent metals such as iron $\left(\mathrm{Fe}^{0}\right)$, zinc $\left(\mathrm{Zn}^{0}\right)$, magnesium $\left(\mathrm{Mg}^{0}\right)$ have been used for the reductive dechlorination of organic compounds Nanoscale zero-valent iron particles have been reported to be very effective for the transformation and detoxification of a wide variety of contaminants, such as arsenic, hexavalent chromium, chlorinated organic solvents, nitroaromatic compounds and azo dyes. Zero-valent metals often result in the production of partially dechlorinated products which are sometimes more toxic than the parent compounds. Also the rate of reactions slow down due to passivation of metals and remediation process may take several days. In this context bimetallic systems offer advantages. Bimetallic systems combine the thermodynamic driving force associated with the corrosion of the reactive metals $\left(\right.$ like $\mathrm{Mg}^{0}$ and $\mathrm{Fe}^{0}$ ) with the catalytic hydrogenation characteristics of the second metal such as zero valent palladium or silver. Dechlorination of pollutants by bimetallic systems is presumed to occur via nucleophilic substitution reactions. The overall rate of the reaction is strongly influenced by the type of substituent groups on the aromatic ring. Commercial application of hydrogenating catalyst such as palladium is limited due to the fact that it is expensive and its recovery after the reduction reaction is very poor. Moreover the presence of trace concentrations of palladium in treated water may exert toxic effects on biological systems. Such problems can be overcome by immobilizing palladium onto suitable support matrices which would enhance its reuse and recovery. Important factors which should be taken into consideration while selecting a support is its stability to by- products, the ease and simplicity with which the catalyst can be immobilized.
\end{abstract}

Keywords: Bimetallic system, chlorinated compound, palladium, reductive transformation, zero-valent metal.

\section{INTRODUCTION}

An emerging abiotic technology for the remediation of recalcitrant pollutants such as chlorinated aliphatic and aromatic compounds is the application of metal systems. The focus of this review article is to provide an overview of the available literature on the application of zero-valent metals, bimetallic systems and immobilized metal (palladium) catalysts for the reductive remediation of pollutants with emphasis on chlorinated compounds.

\section{ZERO VALENT METALS FOR REMEDIATION OF CHLORINATED POLLUTANTS}

Zero-valent metals such as palladium $\left(\mathrm{Pd}^{0}\right)$, iron $\left(\mathrm{Fe}^{0}\right)$, zinc $\left(\mathrm{Zn}^{0}\right)$, magnesium $\left(\mathrm{Mg}^{0}\right)$ have been used for the reductive dechlorination of chlorinated organic compounds. Zerovalent palladium is expensive and requires the presence of hydrogen (or a hydrogen donor) for mediating reductive reactions. The redox couples, namely $\mathrm{Fe}^{2+} / \mathrm{Fe}^{0}, \mathrm{Zn}^{2+} / \mathrm{Zn}^{0}$ and $\mathrm{Mg}^{+2} / \mathrm{Mg}^{0}$ have standard reduction potentials of $-0.44 \mathrm{~V}$, $0.76 \mathrm{~V}$ and $-2.37 \mathrm{~V}$ respectively, with corresponding increase in reactivity towards organic halides. Among the other three metals, iron has been extensively used for dechlorination mainly due its low cost. Table $\mathbf{1}$ gives a partial list of applications of zero-valent metals for reductive transformation of various categories of pollutants.

*Address correspondence to this author at the Centre for Environmental Science and Engineering, Indian Institute of Technology-Bombay, Powai, Mumbai 400 076, India; Tel: 91-22-25767859; E-mail: sumathis@ iitb.ac.in

\section{General Pathways of Dechlorination by Zero-Valent Metals}

The electrochemical reaction is initiated by the corrosion of a base metal with a stronger reducing power (negative reduction potential). Two pathways may contribute to dehalogenation by zero-valent metals as described by Matheson and Tratnyek [1].

The first pathway involves reduction by direct electron transfer from the zero-valent metal such as $\mathrm{Fe}^{0}$ surface to the adsorbed halogenated compound. This process is represented in Fig. (1). In the presence of water and oxygen, the following half reactions (1-3) also occur.

$$
\begin{aligned}
& \mathrm{Fe}(s) \rightarrow \mathrm{Fe}^{+2}(a q)+2 e^{-} \\
& 2 \mathrm{Fe}^{+2}(a q) \rightarrow 2 \mathrm{Fe}^{+3}(a q)+2 e^{-} \\
& \mathrm{O}_{2}+2 \mathrm{H}_{2} \mathrm{O}+4 e^{-} \rightarrow 4 \mathrm{OH}^{-}
\end{aligned}
$$

Ferric and hydroxide ions form stable complex (rust) according to reaction 4 and deposit on the corroding metal surface.

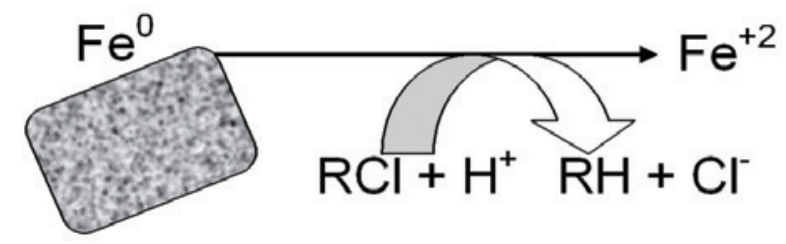

Fig. (1). Reductive dechlorination using $\mathrm{Fe}^{0}$ by direct electron transfer (adapted from [1]). 
Table 1. Application of Zero-Valent Metals in the Degradation of Various Types of Pollutants

\begin{tabular}{|c|c|c|c|c|c|}
\hline $\begin{array}{l}\text { Type of Pol- } \\
\text { lutant }\end{array}$ & $\begin{array}{l}\text { Author(s) and Ref- } \\
\text { erence Number }\end{array}$ & Compound(s) Removed & $\begin{array}{l}\text { Reaction System } \\
\text { Used }\end{array}$ & Reaction Mechanism & Remarks \\
\hline \multirow{4}{*}{$\begin{array}{l}\text { Chlorinated } \\
\text { aromatic }\end{array}$} & $\begin{array}{l}\text { Eykholt and Daven- } \\
\text { port } 1998 \text { [2] }\end{array}$ & $\begin{array}{l}\text { Herbicides Alachlor and } \\
\text { Metolachlor }\end{array}$ & $\mathrm{Fe}^{0}$ & $\begin{array}{l}\text { Hydrogenolysis at the } \\
\text { chloroacetyl group (followed } \\
\text { by N-dealkylation in case of } \\
\text { alachlor) to chloride and } \\
\text { dechlorinated acetanilides }\end{array}$ & $\begin{array}{l}\text { First-order rate con- } \\
\text { stants } \\
0.12 \text { and } 0.1 \text { per hour } \\
\text { for Alachlor and Me- } \\
\text { tolachlor }\end{array}$ \\
\hline & $\begin{array}{l}\text { Ukizu and Miyadera } \\
2005[3]\end{array}$ & Lindane & $\begin{array}{l}\mathrm{Pd}^{0} \text { and alkaline } 2- \\
\text { propanol, aerobic } \\
\text { condition }\end{array}$ & $\begin{array}{l}\text { Complete dechlorination to } \\
\text { benzene }\end{array}$ & $\begin{array}{l}\text { 2-propanol acted as } \mathrm{H}_{2} \\
\text { source; Stoichiometric } \\
\text { reaction with } \mathrm{NaOH} \\
\text { followed by catalytic } \\
\text { dechlorination }\end{array}$ \\
\hline & $\begin{array}{l}\text { Sayles et al. } 1997 \\
\text { [4] }\end{array}$ & DDT, DDD and DDE & $\begin{array}{l}\mathrm{Fe}^{0} \text { (with and with- } \\
\text { out surfactant) } \\
\text { in anaerobic aque- } \\
\text { ous system }\end{array}$ & $\begin{array}{l}\text { Reductive dechlorination to } \\
\text { DDD, DDOH and DDMU } \\
\text { observed }\end{array}$ & $\begin{array}{l}\text { Transformation rate } \\
\text { independent of specific } \\
\text { iron surface area; lim- } \\
\text { ited by mass transfer of } \\
\text { DDT }\end{array}$ \\
\hline & $\begin{array}{c}\text { Schuth and Reinhard } \\
1998[5]\end{array}$ & $\begin{array}{l}\text { Chlorobenzenes, } \\
\text { 4-Chlorobi phenyl, Naph- } \\
\text { thalene and Phenanthrene }\end{array}$ & $\begin{array}{l}\mathrm{Pd}^{0} \text { over alumina in } \\
\text { hydrogen-saturated } \\
\text { water }\end{array}$ & $\begin{array}{l}\text { Hydrodechlorination dehy- } \\
\text { drochlorination and (partial) } \\
\text { hydrogenation } \\
\text { to benzene }\end{array}$ & $\begin{array}{l}\text { Dechlorination reac- } \\
\text { tions faster than hydro- } \\
\text { genation }\end{array}$ \\
\hline \multirow{8}{*}{$\begin{array}{l}\text { Chlorinated } \\
\text { aliphatic and } \\
\text { alicyclic }\end{array}$} & $\begin{array}{c}\text { Matheson and } \\
\text { Tratnyek } 1994 \text { [1] }\end{array}$ & Chlorinated methanes & $\mathrm{Fe}^{0}$ & $\begin{array}{l}\text { Dechlorination by anaerobic } \\
\text { corrosion of iron }\end{array}$ & \\
\hline & $\begin{array}{l}\text { Arnold et al. } 1999 \\
\text { [6] }\end{array}$ & $\begin{array}{l}\text { Polychlorinated } \\
\text { ethanes }\end{array}$ & $\mathrm{Zn}^{0}$ & $\begin{array}{l}\text { Reductive elimination of } \\
\text { halogen atoms }\end{array}$ & \\
\hline & Volpe et al. 2004 [7] & $\begin{array}{l}\text { Herbicide } \\
\text { Triallate }\end{array}$ & $\begin{array}{c}\mathrm{Fe}^{0} \\
\text { anaerobic } \\
\text { conditions }\end{array}$ & $\begin{array}{l}\text { Predominantly reductive } \beta \text { - } \\
\text { elimintation; to a lesser extent } \\
\text { by hydrogenolysis }\end{array}$ & $\begin{array}{l}\text { Complete dechlorina- } \\
\text { tion } \\
\text { to S-allyl- } \\
\text { diisopropylthiocarba- } \\
\text { mate }\end{array}$ \\
\hline & $\begin{array}{l}\text { Orth and Gilham } \\
1996[8]\end{array}$ & $\begin{array}{l}\text { Trichloro } \\
\text { ethylene }\end{array}$ & $\mathrm{Fe}^{0}$ & $\begin{array}{l}\text { Reductive dechlorination by } \\
\text { oxidation of Fe by water }\end{array}$ & $\begin{array}{l}\text { Ethene and ethane are } \\
\text { the end products }\end{array}$ \\
\hline & Mori et al. 2004 [9] & $\begin{array}{l}\text { Trichloro } \\
\text { ethylene }\end{array}$ & $\mathrm{Pd}^{0} /$ silica & Hydrodechlorination & $\begin{array}{l}\text { Ethane is the end prod- } \\
\text { uct }\end{array}$ \\
\hline & $\begin{array}{c}\text { Schlimm and Heitz } \\
1996[10]\end{array}$ & $\begin{array}{c}\text { Lindane } \\
\text { Chloroform } \\
\text { Trichloroethylene }\end{array}$ & $\mathrm{Mg}^{0}$ & Reductive dechlorination & $\begin{array}{l}\text { Products obtained: } \\
\text { benzene and chloroben- } \\
\text { zene; } \\
\text { methane; } \\
\text { ethane \& ethene }\end{array}$ \\
\hline & $\begin{array}{c}\text { Fennelly et al. } \\
1998 \text { [11] }\end{array}$ & Trichloroethylene & $\mathrm{Fe}^{0}$ & $\begin{array}{l}\text { Reductive } \alpha \text {-elimination and } \\
\text { radical/carbenoid coupling to } \\
1,1 \text {-DCA and small amounts } \\
\text { of ethane, cis-2-butene, ethyl- } \\
\text { ene, and a trace of } 2 \text {-butyne. }\end{array}$ & \\
\hline & $\begin{array}{c}\text { Fennelly et al. } 1998 \\
\text { [11] }\end{array}$ & Trichloroethylene & $\mathrm{Zn}^{0}$ & $\begin{array}{l}\text { Reductive } \alpha \text {-elimination and } \\
\text { radical/carbenoid coupling to } \\
\text { ethane and 1,1-DCA }\end{array}$ & \\
\hline \multirow{3}{*}{ Inorganic } & $\begin{array}{c}\text { Dries et al. } 2005 \\
{[12]} \\
\end{array}$ & $\mathrm{Zn}, \mathrm{Ni}$ and $\mathrm{Cr}$ & $\mathrm{Fe}^{0}$ & $\begin{array}{l}\text { Adsorption followed by re- } \\
\text { moval }\end{array}$ & \\
\hline & $\begin{array}{c}\text { Cantrell et al. } 1995 \\
\text { [13] }\end{array}$ & 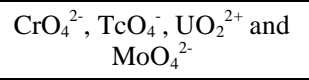 & $\mathrm{Fe}^{0}$ & Reductive precipitation & \\
\hline & Lee et al. 2003 [14] & $\mathrm{Cr}^{6+}$ & $\mathrm{Fe}^{0}$ & Reduction to $\mathrm{Cr}^{3+}$ & $\begin{array}{l}\text { Removal rates faster for } \\
\text { waste iron than with } \\
\text { commercial iron }\end{array}$ \\
\hline
\end{tabular}


(Table 1) contd.....

\begin{tabular}{|c|c|c|c|c|c|}
\hline $\begin{array}{l}\text { Type of Pol- } \\
\text { lutant }\end{array}$ & $\begin{array}{c}\text { Author(s) and } \\
\text { Reference Number }\end{array}$ & Compound(s) Removed & $\begin{array}{c}\text { Reaction System } \\
\text { Used }\end{array}$ & Reaction Mechanism & Remarks \\
\hline \multirow{3}{*}{ Textile dye } & Hou et al. 2007 [15] & $\begin{array}{c}\text { Azo dyes } \\
\text { (Orange I and II \& Methyl } \\
\text { Orange }\end{array}$ & $\begin{array}{c}\mathrm{Fe}^{0} \text {, anaerobic con- } \\
\text { dition }\end{array}$ & $\begin{array}{c}\text { Reductive cleavage of } \\
\text { azo bond to sulfanilic acid } \\
\& \text { another by-product } \\
\text { depending on the substituent } \\
\text { group }\end{array}$ & $\begin{array}{c}\mathrm{Fe}^{0} \text { dosage and } \mathrm{pH} \\
\text { affected the degradation } \\
\text { kinetics }\end{array}$ \\
\hline & $\begin{array}{c}\text { Nam and Tratnyek } \\
2000[16]\end{array}$ & Azo dyes & $\begin{array}{c}\mathrm{Fe}^{0}, \text { anaerobic con- } \\
\text { dition }\end{array}$ & $\begin{array}{l}\text { Reductive cleavage of azo } \\
\text { bond } \\
\text { to sulfanilic acid and } \\
\text { aminonaphthol }\end{array}$ & $\begin{array}{l}\text { Decolorization followed } \\
\text { first-order kinetics }\end{array}$ \\
\hline & Cao et al. 1999 [17] & $\begin{array}{l}\text { Azo dyes (Acid orange II, } \\
\text { Acid orange IV, Acid } \\
\text { orange GG, } \\
\text { Acid red } 3 \text { B and Orange I) }\end{array}$ & $\begin{array}{l}\mathrm{Fe}^{0}, \text { anaerobic con- } \\
\text { dition }\end{array}$ & $\begin{array}{l}\text { Reductive cleavage of azo } \\
\text { bond } \\
\text { to sulfanilic acid and } \\
\text { aminonaphthol }\end{array}$ & $\begin{array}{c}\text { Degradation rates influ- } \\
\text { enced by } \mathrm{pH} \text { and } \mathrm{Fe} \\
\text { surface area }\end{array}$ \\
\hline Nitroaromatic & $\begin{array}{l}\text { Hundal et al. } 1997 \\
\text { [18] }\end{array}$ & TNT and RDX & $\mathrm{Fe}^{0}$ & Reduction to amines & \\
\hline
\end{tabular}

$2 \mathrm{Fe}^{+3}+6 \mathrm{OH}^{-} \rightarrow \mathrm{Fe}_{2} \mathrm{O}_{3}(\mathrm{~s})+3 \mathrm{H}_{2} \mathrm{O}\left[2 \mathrm{Fe}(\mathrm{OH})_{3}\right]$

In the second pathway, an immediate corrosion product of metal such as $\mathrm{Fe}^{+2}$ in aqueous systems, acts as a reductant for dechlorination (Fig. 2). However the metal hydroxide (ferric hydroxide in the case of iron, Equation 4) produced during corrosion leads to the rapid passivation of the zerovalent iron (deactivation of the metal) and thereby reduces the rate of dechlorination reactions. In this context, $\mathrm{Mg}^{0}$ has a distinct advantage over $\mathrm{Fe}^{0}$ in that the magnesium hydroxides produced are relatively more soluble $\left(\mathrm{pKsp} \mathrm{Mg}(\mathrm{OH})_{2}=\right.$ 11.5 vs pKsp $\left.\mathrm{Fe}(\mathrm{OH})_{2}=15.1\right)$ thereby decreasing the passivation of the corroding metal [19].

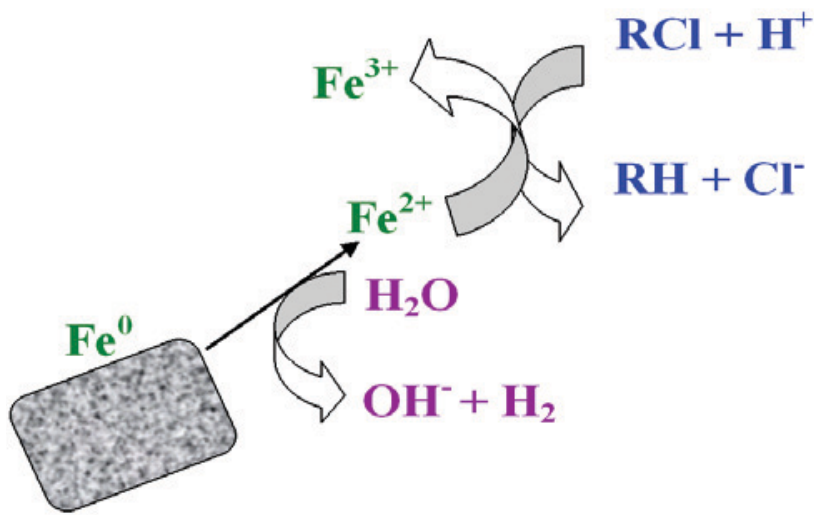

Fig. (2). Reductive dechlorination using $\mathrm{Fe}^{0}-\mathrm{H}_{2} \mathrm{O}$ system in which $\mathrm{Fe}^{2+}$ acts as the dehalogenating agent (adapted from [1]).

\section{Use of Nanoscale Zero-Valent Iron Particles (NZVI)}

Nanoparticles (1-100 nm) which provide higher surfacearea-to-volume ratio can lead to enhanced reactivity with environmental contaminants that degrade through adsorption mechanism. Zero-valent iron nanoparticles have been reported to be very effective for the transformation and detoxification of a wide variety of contaminants, such as arsenic [20], hexavalent chromium [21], chlorinated organic solvents and nitroaromatic compounds [22]. Shu et al. demonstrated reduction of azo dye, Acid Red Black 24 using chemically synthesized nanoscale zero-valent iron (NZSVI) particles [23].

\section{Field-Scale Application of Zero-Valent Iron}

Zero-valent iron has been applied to field-scale remediation of contaminated waters. Permeable reactive barriers (PRB) packed with iron particles have been positioned in the subsurface across the flow path of groundwater for facilitating reductive dehalogenation of halogenated contaminants. PRB technology represents an attractive alternative technology to traditional pump-and-treat systems and offers advantages such as low energy consumption and minimal operation and maintenance costs. Iron PRBs were first developed in USA and Canada [24]. Presently, several PRB configurations are commercially available around the world.

\section{Disadvantages of Zero-Valent Systems in Effecting Dechlorination}

Zero-valent metals such as iron, zinc or magnesium often result in the production of partially dechlorinated products which are sometimes more toxic than the parent compounds [25]. Also the rate of reactions slow down due to passivation of metals and remediation process may take several days [26]. In this context bimetallic systems provide distinct advantages.

\section{BIMETALLIC SYSTEMS FOR REDUCTIVE RE- ACTIONS}

Rapid dehalogenation can occur if an effective hydrogenating catalyst (such as Pd) is combined with zero-valent metals as shown in Fig. (3) [25, 27-30]. Such systems combine the thermodynamic driving force associated with the corrosion of the reactive metals (like $\mathrm{Mg}^{0}$ and $\mathrm{Fe}^{0}$ ) with the catalytic hydrogenation characteristics of the second metal such as zero-valent palladium or silver [31]. The second metal primarily has the following functions: i) acts as a hydrogenating catalyst ii) prevents the formation of the oxide film on the surface of the metal [32] and iii) induces zero-valent metal to release electrons due to the difference in reduction potentials. The corrosion rate of the base metal is also expected to increase by the coated catalytic metal (such as palladium) as a result of galvanic reaction [33]. Table 2 shows 
Table 2. Application of Bimetallic Systems in the Degradation of Various Types of Pollutants

\begin{tabular}{|c|c|c|c|c|c|}
\hline $\begin{array}{l}\text { Category of } \\
\text { Pollutant }\end{array}$ & $\begin{array}{l}\text { Author(s) } \\
\text { (Year) }\end{array}$ & $\begin{array}{l}\text { Compound(s) } \\
\text { Removed }\end{array}$ & Reaction System Used & Reaction Mechanism & Remarks \\
\hline \multirow{10}{*}{$\begin{array}{l}\text { Chlorinated } \\
\text { aromatic }\end{array}$} & $\begin{array}{c}\text { Gautam and } \\
\text { Suresh } 2007 \\
{[35]}\end{array}$ & DDT & $\begin{array}{c}\mathrm{Mg}^{0} / \mathrm{Pd} \text { system, } \\
\text { acetone, } 0.05 \% \text { biosur- } \\
\text { factant, acid }\end{array}$ & $\begin{array}{l}\text { Reductive (complete) dechlo- } \\
\text { rination to diphenyl } \\
\text { ethane }\end{array}$ & $\begin{array}{l}\text { Biosurfactant used for the solubili- } \\
\text { zation of DDT }\end{array}$ \\
\hline & $\begin{array}{c}\text { Gautam and } \\
\text { Suresh } 2006 \\
{[28]}\end{array}$ & $\begin{array}{l}\text { DDT, DDD and } \\
\text { DDE in soil } \\
\text { slurry }\end{array}$ & $\begin{array}{c}\mathrm{Mg}^{0} / \mathrm{Pd} \\
\text { (water-acetone / } 0.05 \% \\
\text { biosurfactant- water } \\
\text { with acid) }\end{array}$ & $\begin{array}{l}\text { Reductive (complete) dechlo- } \\
\text { rination of all three com- } \\
\text { pounds to diphenyl ethane }\end{array}$ & $\begin{array}{c}\text { Acetone \& biosurfactant used for } \\
\text { the solubilization of DDT, DDD and } \\
\text { DDE }\end{array}$ \\
\hline & $\begin{array}{l}\text { Engelmann } \\
\text { et al. } 2001 \\
\quad[19]\end{array}$ & DDT & $\begin{array}{c}\mathrm{Mg} / \mathrm{Pd} \text {, acetone-water, } \\
\text { acid }\end{array}$ & $\begin{array}{c}\text { Reductive dechlorination to } \\
\text { diphenyl ethane, diphenyl } \\
\text { methane and tetraphenyl bu- } \\
\text { tane. }\end{array}$ & $\begin{array}{l}\text { No toxic intermediates like DDD } \\
\text { and DDE were produced }\end{array}$ \\
\hline & $\begin{array}{l}\text { Engelmann et } \\
\text { al. } 2003[31]\end{array}$ & $\mathrm{PCB}$ and DDT & $\begin{array}{l}\mathrm{Fe} / \mathrm{Pd} \\
\mathrm{Mg} / \mathrm{Pd}\end{array}$ & $\begin{array}{l}\text { Reductive dechlorination to } \\
\text { biphenyl and } \\
\text { diphenylethane }\end{array}$ & $\begin{array}{l}\text { Initially } \mathrm{Fe} / \mathrm{Pd} \text { produced mono- and } \\
\text { di-chloro congeners followed by } \\
\text { production of biphenyl by } \mathrm{Mg} / \mathrm{Pd}\end{array}$ \\
\hline & $\begin{array}{l}\text { Grittini et al. } \\
1995 \text { [25] }\end{array}$ & PCB & $\begin{array}{c}\mathrm{Pd} / \mathrm{Fe} \text { system, metha- } \\
\text { nol/water/acetone } \\
\text { phase }\end{array}$ & $\begin{array}{l}\text { Reductive dechlorination of } \\
\text { adsorbed PCB to Biphenyl }\end{array}$ & $\begin{array}{l}\text { Reaction rate influenced by } \% \mathrm{Pd} \\
\text { deposited on Fe, amount of } \mathrm{Pd} / \mathrm{Fe} \\
\text { used and } \% \text { of water in the system }\end{array}$ \\
\hline & $\begin{array}{c}\text { Patel and } \\
\text { Suresh 2006b } \\
{[29]}\end{array}$ & $\begin{array}{l}\text { Pentachlorophe- } \\
\text { nol (PCP) }\end{array}$ & $\mathrm{Mg}^{0} / \mathrm{Ag}^{0}$, acid & $\begin{array}{l}\text { Sequential (complete) dechlo- } \\
\text { rination to phenol }\end{array}$ & $\begin{array}{c}\text { Efficiency of PCP }\left(10 \mathrm{mg} \mathrm{L}^{-1}\right) \text { re- } \\
\text { moval was } 35 \% \text { in the absence of } \\
\text { acid }\end{array}$ \\
\hline & $\begin{array}{c}\text { Patel and } \\
\text { Suresh } 2007 \\
{[30]} \\
\end{array}$ & $\begin{array}{l}\text { Chlorinated phe- } \\
\text { nols }\end{array}$ & $\mathrm{Mg}^{0} / \mathrm{Pd}^{0}$ & $\begin{array}{c}\text { Reductive } \\
\text { dechlorination to phenol }\end{array}$ & $\begin{array}{c}\text { Dechlorination rates increased with } \\
\text { decrease in } \mathrm{Cl} \text { atoms }\end{array}$ \\
\hline & $\begin{array}{c}\text { Kim and Car- } \\
\text { raway } 2000 \\
{[36]} \\
\end{array}$ & $\begin{array}{l}\text { Pentachlorophe- } \\
\text { nol }\end{array}$ & $\begin{array}{c}\mathrm{Pd} / \mathrm{Fe}, \mathrm{Pt} / \mathrm{Fe}, \mathrm{Ni} / \mathrm{Fe} \text { and } \\
\mathrm{Cu} / \mathrm{Fe}\end{array}$ & $\begin{array}{l}\text { Removal by sorption } \\
\text { and dechlorination to } \\
\text { tetrachlorophenol }\end{array}$ & $\begin{array}{c}\text { Rates of dechlorination by bimetals } \\
\text { lower than untreated Fe }\end{array}$ \\
\hline & $\begin{array}{l}\text { Morales } \\
\text { et al. } 2002 \\
{[37]} \\
\end{array}$ & Phenol & $\mathrm{Pd} / \mathrm{Mg}$ and $\mathrm{Pd} / \mathrm{Fe}$ & Hydrogenation & $\begin{array}{l}\text { Cyclohexanone and cyclohexanol } \\
\text { were the end products }\end{array}$ \\
\hline & $\begin{array}{l}\text { Zinovyev } \\
2004[38]\end{array}$ & Lindane & $\begin{array}{l}\text { Isooctane-base, } \\
\text { a phase-transfer agent } \\
\text { (Aliquat } 336) \text { and a } \\
\text { metal catalyst }(\mathrm{Pd} / \mathrm{C}, \\
\mathrm{Pt} / \mathrm{C} \text { and Raney-Ni) }\end{array}$ & $\begin{array}{l}\text { Base-assisted dehydrochlori- } \\
\text { nation followed by hy- } \\
\text { drodechlorination }\end{array}$ & $\begin{array}{l}\text { Aliquat } 336 \text { produced a } 10 \text {-fold rate } \\
\text { increase, alkaline water avoids } \\
\text { catalyst poisoning by neutralizing } \\
\text { the hydrochloric acid formed. }\end{array}$ \\
\hline \multirow{7}{*}{$\begin{array}{l}\text { Chlorinated } \\
\text { aliphatic }\end{array}$} & $\begin{array}{l}\text { Muftikan } \\
\text { et al. } \\
1995[39]\end{array}$ & $\begin{array}{l}\mathrm{CCl}_{4}, \mathrm{CHCl}_{3} \text { and } \\
\mathrm{CH}_{2} \mathrm{Cl}_{2} \\
\text { di-,tri- and tetra- } \\
\text { chloro } \\
\text { ethylenes } \\
\end{array}$ & $\mathrm{Pd} / \mathrm{Fe}$ & $\begin{array}{l}\text { Reductive hydro- } \\
\text { dechlorination to ethane } \\
\text { and methane }\end{array}$ & $\begin{array}{c}\text { Dechlorination rates decreased with } \\
\text { decrease in } \mathrm{Cl} \text { atoms }\end{array}$ \\
\hline & $\begin{array}{l}\text { Feng and Lim } \\
2005[40]\end{array}$ & $\mathrm{CCl}_{4}$ and $\mathrm{CHCl}_{3}$ & $\begin{array}{l}\text { Nanosized } \mathrm{Pd} / \mathrm{Fe} \text { and } \\
\mathrm{Fe}\end{array}$ & $\begin{array}{c}\text { Reductive } \\
\text { dechlorination }\end{array}$ & $\begin{array}{l}\text { Reaction rates } 2-8 \text { times higher than } \\
\text { that of commercial microscale } \mathrm{Zn} \& \\
\qquad \mathrm{Fe}\end{array}$ \\
\hline & $\begin{array}{c}\text { Wang and } \\
\text { Zhang } 1997 \\
\text { [32] }\end{array}$ & TCE and PCBs & Nanoscale $\mathrm{Pd} / \mathrm{Fe}$ & $\begin{array}{l}\text { Dechlorination to } \\
\text { hydrocarbons } \\
\text { and biphenyl }\end{array}$ & $\begin{array}{c}\text { Surface-area-normalized } \\
\text { rate constants were } 10-100 \text { times } \\
\text { higher than those of commercially } \\
\text { available iron particles }\end{array}$ \\
\hline & $\begin{array}{c}\text { Korte et al. } \\
2000[41]\end{array}$ & Trichloroethane & $\mathrm{Pd} / \mathrm{Fe}$ & $\begin{array}{c}\text { Complete } \\
\text { dechlorination }\end{array}$ & Formation of sulfide poisoned Pd \\
\hline & $\begin{array}{c}\text { Cheng and } \\
\text { Wu } 2000 \text { [27] }\end{array}$ & Trichloroethylene & $\mathrm{Zn} / \mathrm{Pd}$ and $\mathrm{Zn} / \mathrm{Ni}$ & $\begin{array}{c}\text { Reductive } \\
\text { dechlorination }\end{array}$ & $\begin{array}{c}\text { Degradation of TCE by } \mathrm{Zn}^{0} \text { was } 10 \\
\text { times higher than that by } \mathrm{Fe}^{0}\end{array}$ \\
\hline & $\begin{array}{l}\text { Fennelly } \\
\text { et al. } 1998 \\
\quad[11]\end{array}$ & Trichloroethylene & $\mathrm{Cu} / \mathrm{Fe}^{0}$ & $\begin{array}{l}\text { Reductive elimination and } \\
\text { radical/carbenoid coupling to } \\
\text { 1,1-DCA, ethylene, cis 2- } \\
\text { butene, } \\
\text { 2-butyne }\end{array}$ & \\
\hline & $\begin{array}{l}\text { Fennelly } \\
\text { et al. } \\
1998[11]\end{array}$ & Trichloroethylene & $\mathrm{Ni} / \mathrm{Fe}^{0}$ & $\begin{array}{l}\text { Reductive elimination and } \\
\text { radical/carbenoid coupling to } \\
\text { cis 2-butene, ethylene, } 1,1- \\
\text { DCA, trace of 2-butyne } \\
\text { formed }\end{array}$ & \\
\hline Textile dye & $\begin{array}{c}\text { Patel and } \\
\text { Suresh 2006a } \\
{[42]}\end{array}$ & $\begin{array}{l}\text { Reactive black } 5 \\
\text { Sunset yellow } \\
\text { FCF and Tar- } \\
\text { trazine dyes }\end{array}$ & $\mathrm{Mg}^{0} / \mathrm{Pd}^{+4}$ & $\begin{array}{l}\text { Reductive cleavage of azo } \\
\text { bonds to amines }\end{array}$ & $\begin{array}{l}\text { Reaction followed first-order } \\
\text { kinetics }\end{array}$ \\
\hline
\end{tabular}


the summary of literature available on the application of bimetallic systems for reductive remediation of various classes of pollutants. The hydrogenating catalyst may be spatially separated from the corroding zero-valent metal or doped on the latter (bimetallic system). Reductive hydrodechlorination follows the sequence: a) evolution of hydrogen gas by the reduction of protons which results through the corrosion of the base metal b) intercalation of hydrogen in the lattice of hydrogenating catalyst like palladium $\left(\mathrm{Pd}^{0}\right)$ to generate the powerful reducing species metal hydride $(\mathrm{Pd}-$ $\mathrm{H}) \mathrm{c}$ ) reductive dechlorination of the chlorinated compound by the metal hydride [34]. Dechlorination of pollutants by bimetallic systems is presumed to occur via nucleophilic substitution reactions and involves two steps. The overall rate of the reaction is strongly influenced by the type of substituent groups on the aromatic ring. The two general mechanisms for reductive dechlorination are considered in the following sub-sections.

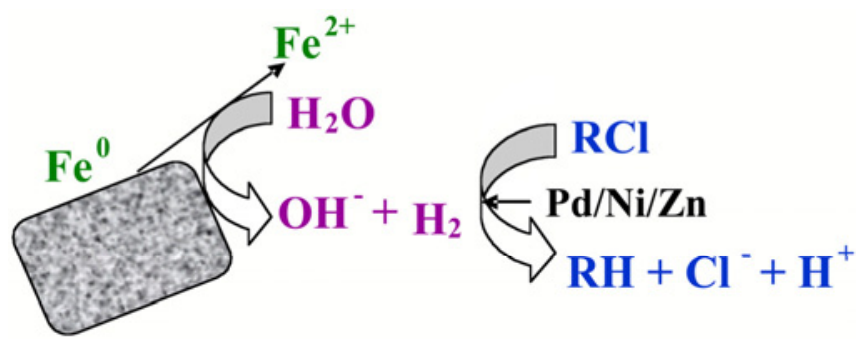

Fig. (3). Reductive dechlorination using $\mathrm{Fe}^{0}-\mathrm{H}_{2} \mathrm{O}$ system and molecular hydrogen. (adapted from [1]).

Mechanism-1: The first step is the attack of nucleophilic species (such as silver hydride) on the aromatic ring to give the transient carbanion [29]. This is followed by the expulsion of halide ion from the carbanion, which is much faster as compared to the first step. The transient carbanion contains a tetrahedral carbon and the negative charge is distributed around the aromatic ring. Substituting groups (such as $\mathrm{Cl}$ atoms) that withdraw electrons will help to neutralize (disperse) the negative charge on the ring and stabilize the carbanion. Thus, the greater the number of chlorine atoms on the ring (as in pentachlorophenol), the easier is the first nucleophilic substitution (and dechlorination) due to the enhanced stability of transition state.

Mechanism-2: The first step is possibly the slow and direct heterolytic cleavage of $\mathrm{C}-\mathrm{Cl}$ bond accompanied by the formation of a transient carbocation on the aromatic ring [30]. In the second step the unstable carbocation combines rapidly with a nucleophile (such as palladium hydride) to complete the octet of the positively charged carbon. In the case of chlorophenols, the stability of transient carbocation and hence the overall rate of dechlorination is determined by the number of electron-withdrawing substituent groups such as chlorine atoms on the ring. More chlorine atoms on the ring (as in the case of pentachlorophenol) tend to intensify the positive charge on the aromatic ring, destabilizing the carbocation thereby reducing the overall rate of dechlorination reaction.

\section{Examples of Reductive Degradation Reactions Mediated by Bimetallic Systems}

\section{Example-1: Reductive Dechlorination of DDT by Magne- sium-Palladium Bimetallic System}

Gautam and Suresh proposed the sequence of events leading to the reductive dechlorination of DDT to diphenylethane (DPE) by the bimetallic system, $\mathrm{Mg} / \mathrm{Pd}$ system as shown in Fig. (4) [28]. First, zero-valent magnesium undergoes corrosion in the presence of water resulting in $\mathrm{Mg}^{2+}$ and electrons. These electrons are accepted by protons to produce molecular hydrogen which is absorbed by palladium to generate reactive species of hydrogen. The latter reacts with DDT molecules adsorbed on the surface of the bimetal resulting in the sequential removal of aromatic followed by aliphatic chlorine atoms to generate the hydrocarbon end product, diphenylethane (DPE).

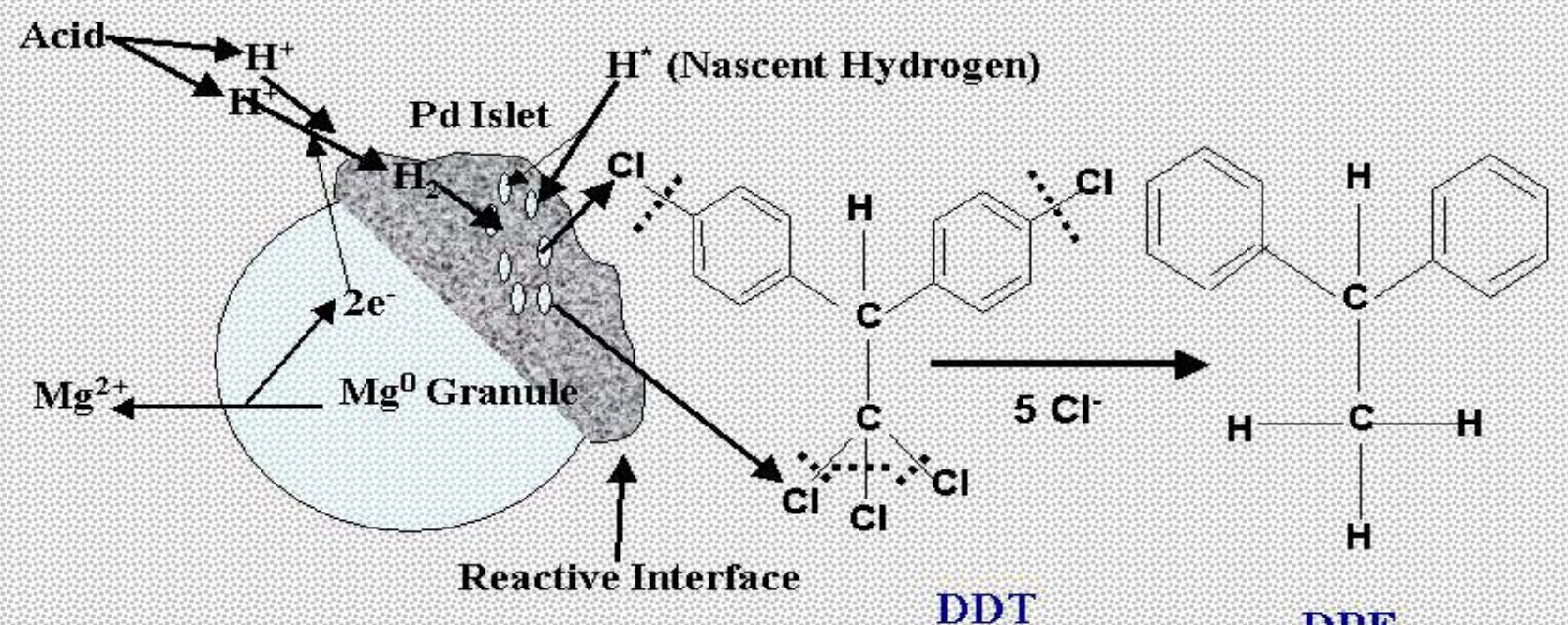

\section{Soil Slurry (Acidic Condition)}

Fig. (4). Reductive dechlorination of DDT to diphenylethane (DPE) by magnesium-palladium system [28]. 


\section{Example-2: Dechlorination of PCP by Magnesium-Silver Bimetallic System}

Patel and Suresh reported more than $85 \%$ removal of 10 $\mathrm{mg} \mathrm{L}^{-1}$ of pentachlorophenol (PCP) by magnesium/silver $(206 \mathrm{mM} / 1.47 \mathrm{mM})$ bimetal system in the presence of acetic acid [29]. Dechlorination was found to be sequential and phenol was identified as ultimate hydrocarbon skeleton along with some accumulation of tetra, tri and dichlorophenols. Dechlorination reaction was found to follow second order kinetics. A diagrammatic sequence of events during the course of dechlorination of PCP by magnesium-silver bimetallic system is represented in Fig. (5).

\section{Example-3: Reductive Decolourization of Reactive Black} Dye

Patel and Suresh reported $\mathrm{Mg} / \mathrm{Pd}$ (palladium in the form of $\mathrm{K}_{2} \mathrm{PdCl}_{6}$ or $\mathrm{Pd}^{\mathrm{o}}$-alumina pellets) mediated reductive reactions for decolourization of reactive black 5 , sunset yellow FCF and tartrazine dyes [42]. The authors reported permanent and complete loss of visible range absorption peaks. The extent of colour removal exceeded $95 \%$ within $24 \mathrm{~h}$ of reaction. The authors hypothesized that this heterogeneous phase catalytic process occurred at the interface between $\mathrm{Mg}^{\mathrm{O}} / \mathrm{Pd}^{\mathrm{o}}$ or on $\mathrm{Pd}^{\mathrm{o}}$ particles. LC-MS data suggested that the loss of colour was due to the reductive cleavage of $-\mathrm{N}=\mathrm{N}-$ (azo) in the dye molecules (Fig. 6).

\section{Factors to be Considered for the Application of Bimetallic Systems}

Some of the key factors that need to be considered for the field scale application of bimetallic systems are: a) effect of environmental parameters that affect the long term stability and performance of bimetallic systems b) concentration and cost of metals involved c) types of reaction products accumulated and d) toxicity of dissolved metal ions in the treated water, soil or slurry.

\section{IMMOBILIZED NOBLE METALS FOR THE DEG- RADATION OF POLLUTANTS}

Among the noble metals, palladium is the best choice hydrogenating catalyst (such as in bimetallic systems) for the reductive transformation and degradation of various classes of pollutants (as is evident from Table 2). However its commercial application is limited due to the fact that it is an expensive catalyst and its recovery after the reduction reaction is very poor. Moreover the presence of trace concentrations of palladium in treated water may exert toxic effects on biological systems. The above stated problems can be overcome by immobilizing the catalyst onto suitable supports which would enhance its reuse and recovery. Various types of supports have been used for the immobilization of palladium which includes inorganic ones such as alumina, silica, zeolites; metal oxides such as $\mathrm{TiO}_{2}, \mathrm{MgO}, \mathrm{ZrO}_{2}$; and organic ones such as cellulose, chitin, chitosan, and aminoacids [43, 44]. Table 3 presents the literature available for the use of immobilized palladium as a catalyst for the degradation of chlorinated pollutants. Cagnola et al. (2004) reiterated the advantages of supported catalyst complexes compared to homogenous systems because of easy separation from the treated solution [45]. Morales et al. also observed that Pd supported on alumina could be easily recovered compared to the unsupported bimetallic systems [37]. However commercially available immobilized palladium catalysts such as palladium supported on carbon or Pd-alumina are very costly. Moreover, the selectivity of the catalyst to the target compound, the catalyst activity and stability of the catalyst are strongly influenced by the type of support material $[43,59]$.

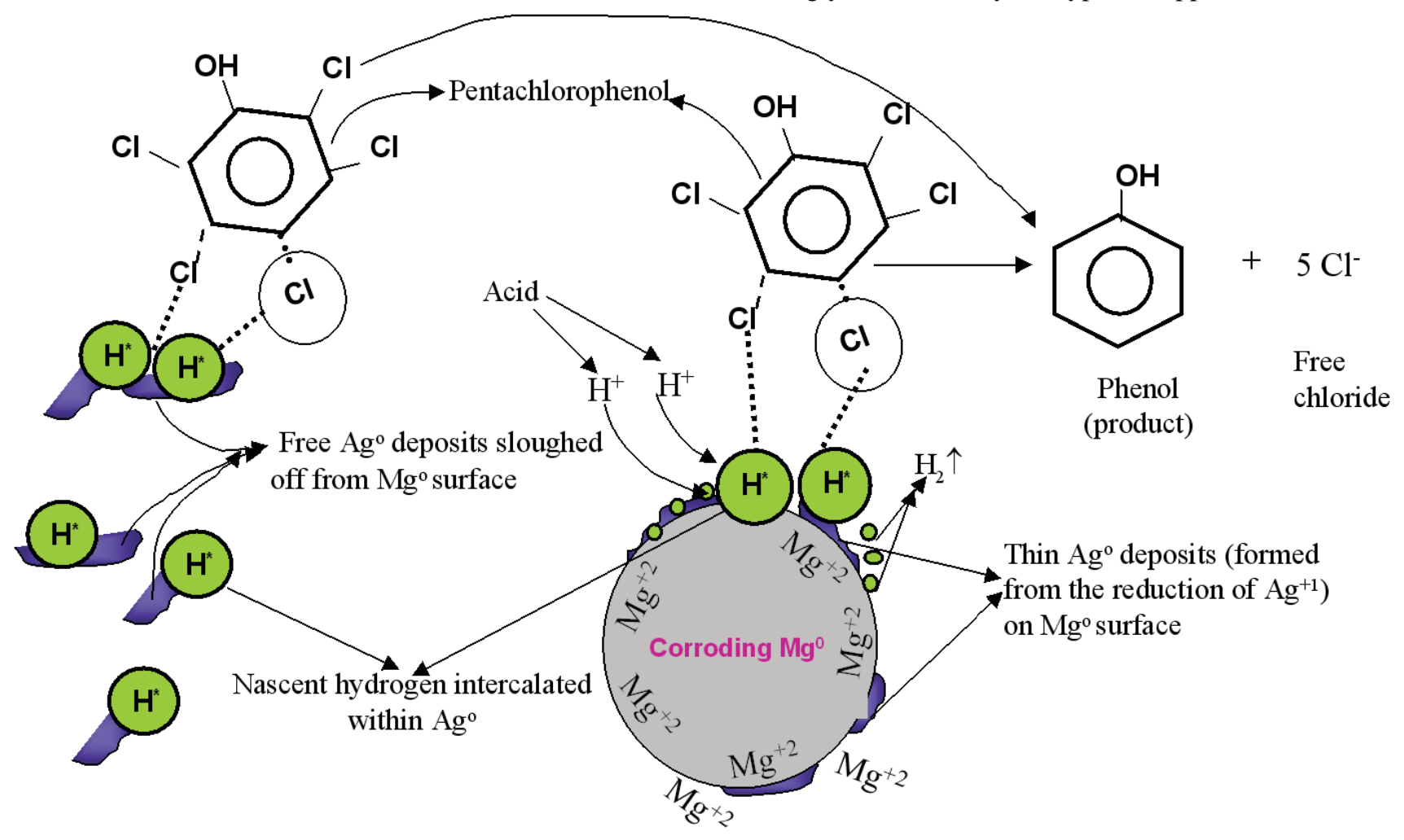

Fig. (5). Representation of events occuring during dechlorination of pentachlorophenol by $\mathrm{Mg} / \mathrm{Ag}$ system [29]. 
<smiles>Nc1ccc(OS(=O)(=O)OCCCCS)cc1</smiles>

1sulphonic, 2-(4aminobenzenesulphonyl) ethanol (M.W. 280.9)<smiles>Nc1c(S(=O)(=O)[O-])cc2cc(S(=O)(=O)[O-])c(N)c(O)c2c1N</smiles>

1-2-7-triamino-8-hydroxy 3-6-naphthalinedisulphonate (M.W. 349)

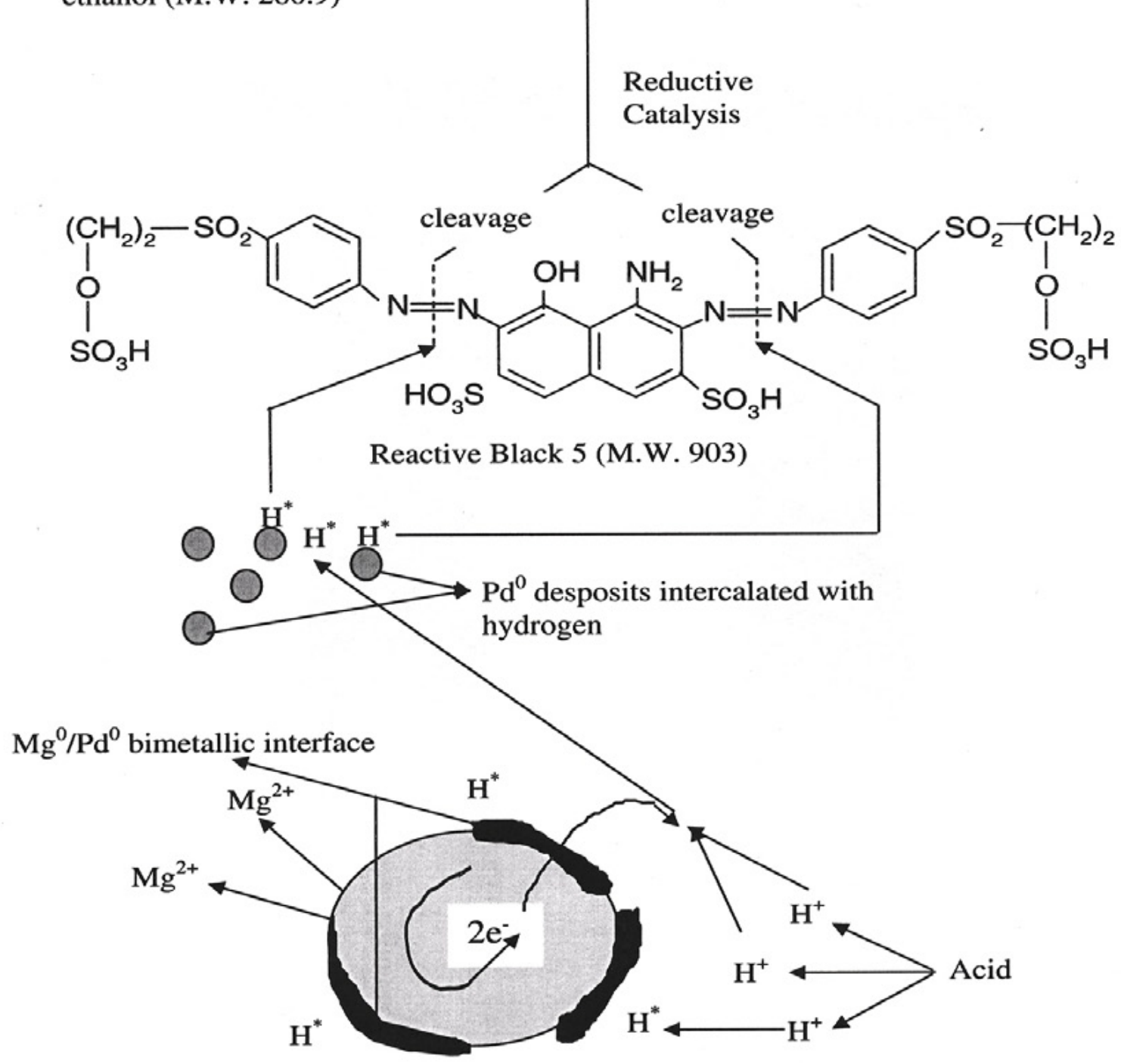

Corroding magnesium granule

Fig. (6). Decolourization of reactive black 5 dye by magnesium-palladium system [42].

Most of the inorganic supports are also attacked and damaged by $\mathrm{HCl}$ released as a product of the dechlorination reaction. In addition inorganic supports also undergo unwanted reactions such as ion exchange, with $\mathrm{HCl}$, leading to loss of selectivity and activity of the catalyst [43]. Reduction in the catalyst activity due to poisoning of support by chloride ions released from the catalyst precursor has also been reported
[60]. Thus a catalyst support, which is resistant to corrosion by hydrogen halide, would ensure high activity and stability of palladium [43]. Apart from these, another important factor which should be taken into consideration while selecting a support is the ease and simplicity with which the catalyst can be immobilized on the support material. 
Table 3. Dechlorination of Chlorinated Compounds by Palladium Immobilized on Various Support Materials

\begin{tabular}{|c|c|c|c|c|}
\hline $\begin{array}{l}\text { Author(s) and } \\
\text { References }\end{array}$ & Compound(s) Degraded & Reaction System Used & Reaction Mechanism & Remarks \\
\hline $\begin{array}{c}\text { Schuth and } \\
\text { Reinhard } 1998 \\
\text { [5] }\end{array}$ & $\begin{array}{c}\text { 1,2 -dichlorobenzene, } \\
\text { chlorobenzene, } \\
4 \text {-chlorobiphenyl, } \\
\text { y-hexachlorocyclohexane } \\
\text { (Lindane), naphthalene and } \\
\text { phenanthrene }\end{array}$ & $\begin{array}{l}\text { Palladium on alumina in } \\
\text { hydrogen-saturated water at } \\
\text { room temperature and ambi- } \\
\text { ent pressure }\end{array}$ & $\begin{array}{l}\text { Hydrodechlorination dehy- } \\
\text { drochlorination and (partial) } \\
\text { hydrogenation to benzene }\end{array}$ & $\begin{array}{c}\text { Dechlorination reactions faster than } \\
\text { hydrogenation }\end{array}$ \\
\hline $\begin{array}{c}\text { Schreier and } \\
\text { Reinhard } 1995 \\
\text { [46] }\end{array}$ & Chlorinated ethylenes & $\begin{array}{c}\text { Palladium on alumina and } \\
\text { hydrogen }\end{array}$ & $\begin{array}{l}\text { Hydrodehalogenation and } \\
\text { hydrogenation to ethane }\end{array}$ & $\begin{array}{l}\text { Presence of bisulfide poisoned the } \\
\text { catalyst }\end{array}$ \\
\hline $\begin{array}{l}\text { Hoke } \text { et al. } \\
1992 \text { [47] }\end{array}$ & Chlorinated phenols & $\begin{array}{l}\text { Palladium on carbon, ammo- } \\
\text { nium hydroxide and hydro- } \\
\text { gen }\end{array}$ & $\begin{array}{l}\text { Hydrodechlorination to } \\
\text { phenol }\end{array}$ & $\begin{array}{l}\text { Rate of dechlorination decreased with } \\
\text { increase in chlorine substitution }\end{array}$ \\
\hline $\begin{array}{l}\text { Zhang et al. } \\
\text { 2007a [48] }\end{array}$ & $\begin{array}{l}\text { Octachlorodibenzo-p- } \\
\quad \text { dioxin (OCDD) }\end{array}$ & $\begin{array}{l}\text { Palladium on carbon, } \mathrm{H}_{2}, \\
\text { ethanol-water solution of } \\
\mathrm{NaOH}, 50^{\circ} \mathrm{C}, 3 \text { h of reaction }\end{array}$ & $\begin{array}{l}\text { Hydrodechlorination under } \\
\text { mild conditions }\end{array}$ & $\begin{array}{l}96 \% \text { of OCDD was degraded to low } \\
\text { dechlorinated congeners. The yield of } \\
\text { dibenzo-p-dioxin was } 77 \%\end{array}$ \\
\hline $\begin{array}{l}\text { Zhang et al. } \\
\text { 2007b [49] }\end{array}$ & $\begin{array}{l}\text { Polychlorinated dibenzo- } p- \\
\text { dioxins (PCDDs) }\end{array}$ & $\begin{array}{l}\text { Palladium on carbon, } \mathrm{H}_{2} \text {, } \\
\text { ethanol-water solution of } \\
\mathrm{NaOH}, 50^{\circ} \mathrm{C}, 6 \mathrm{~h} \text { of reaction }\end{array}$ & $\begin{array}{l}\text { Hydrodechlorination under } \\
\text { mild conditions }\end{array}$ & Chlorine-free products obtained \\
\hline $\begin{array}{l}\text { Ukizu et al. } \\
2000[50]\end{array}$ & $\begin{array}{l}\text { Chlorobenzene, } p \text {-chloro } \\
\text { toluene, and } 4- \\
\text { chlorobiphenyl }\end{array}$ & $\begin{array}{l}\mathrm{Rh} \text { - Platinum on carbon, } \\
\mathrm{NaOH} \text { solution in } 2- \\
\text { propanol, anaerobic condi- } \\
\text { tion, } 35^{\circ} \mathrm{C}\end{array}$ & $\begin{array}{l}\text { Dechlorination to benzene, } \\
\text { toluene and biphenyl }\end{array}$ & $\begin{array}{l}\text { Deactivation of catalyst due to accu- } \\
\text { mulation of } \mathrm{NaCl} \text {; reactivation of } \\
\text { catalyst by washing with water }\end{array}$ \\
\hline Author(s) & Compound(s) degraded & Reaction system used & Reaction mechanism & Remarks \\
\hline $\begin{array}{c}\text { Yuan and } \\
\text { Keane 2004 } \\
\text { [51] }\end{array}$ & Chlorophenols & $\begin{array}{l}\text { Palladium on carbon and } \\
\text { Palladium on aluminate }\end{array}$ & $\begin{array}{l}\text { Hydrodechlorination to } \\
\text { phenol }\end{array}$ & $\begin{array}{l}\text { Reuse of } \mathrm{Pd} / \mathrm{C} \text { limited due to deactiva- } \\
\text { tion by } \mathrm{HCl} \text {; limited loss of activity in } \\
\text { case of } \mathrm{Pd} / \mathrm{Al}_{2} \mathrm{O}_{3}\end{array}$ \\
\hline $\begin{array}{c}\text { Ukizu and } \\
\text { Miyadera } 1997 \\
\text { [52] }\end{array}$ & 1,2,4-trichlorobenzene & $\begin{array}{l}\text { Palladium on carbon, 2- } \\
\text { propanol solution of } \mathrm{NaOH}, \\
\text { anaerobic condition }\end{array}$ & $\begin{array}{l}\text { Hydrodechlorination to } \\
\text { benzene }\end{array}$ & $\begin{array}{c}\mathrm{NaOH} \text { prevents catalyst deactivation } \\
\text { and promotes 2-propanol dehydroge- } \\
\text { nation }\end{array}$ \\
\hline $\begin{array}{c}\text { Ukizu and } \\
\text { Miyadera } 2003 \\
{[53]}\end{array}$ & $\begin{array}{l}\text { Polychlorinated dibenzo- } p \text { - } \\
\text { dioxins and dibenzo furans }\end{array}$ & $\begin{array}{l}\text { Palladium on carbon, 2- } \\
\text { propanol solution of } \mathrm{NaOH}, \\
\text { anaerobic condition }\end{array}$ & $\begin{array}{l}\text { Hydrodechlorination to } \\
\text { chlorine-free products }\end{array}$ & $\begin{array}{l}\mathrm{NaOH} \text { promoted dechlorination reac- } \\
\text { tion }\end{array}$ \\
\hline $\begin{array}{l}\text { Aramendia } e t \\
\text { al. } 2001[54]\end{array}$ & Chlorobenzene & $\begin{array}{l}\text { Palladium on PM2 (alumin- } \\
\text { ium ortho phosphate and } \\
\text { silica) }\end{array}$ & $\begin{array}{l}\text { Hydrodechlorination to } \\
\text { benzene }\end{array}$ & $\begin{array}{l}\text { Addition of } \mathrm{NaOH} \text { ineffective in neu- } \\
\text { tralizing the } \mathrm{HCl} \text { formed; } \mathrm{NaOH} \text { dam- } \\
\text { ages the porous support and dissolves } \\
\text { palladium metal }\end{array}$ \\
\hline $\begin{array}{l}\text { Patel and } \\
\text { Suresh 2008 } \\
\quad[55]\end{array}$ & Pentachlorophenol (PCP) & $\begin{array}{l}\text { Palladium immobilized on } \\
\text { bacterial cellulose }\end{array}$ & $\begin{array}{l}\text { Pentechlorophenol dechlori- } \\
\text { nated all the way to phenol }\end{array}$ & $\begin{array}{l}\text { Approximately } 12 \mathrm{~L} \text { and } 11 \mathrm{~L} \text { of } 40 \\
\mathrm{mg} \mathrm{L} \mathrm{L}^{-1} \mathrm{PCP}(\mathrm{pH} 6.5) \text { could be treated } \\
\text { in RCCR with } 99 \% \text { and } 80 \% \text { efficien- } \\
\text { cies in batch and continuous flow } \\
\text { modes, respectively without any ap- } \\
\text { preciable loss of the catalytic activity. }\end{array}$ \\
\hline $\begin{array}{l}\text { Hoke } \text { et al. } \\
1992[47]\end{array}$ & PCP & $\mathrm{Pd} / \mathrm{C}$ and hydrogen & $\begin{array}{l}\text { Hydrodechlorination to } \\
\text { phenol with an yield of } 98 \%\end{array}$ & $\begin{array}{l}\text { Completely anaerobic conditions } \\
\text { required. Reaction conducted in water } \\
+ \text { ethanol }(1: 1)\end{array}$ \\
\hline $\begin{array}{l}\text { Roy et al. } 2004 \\
{[56]}\end{array}$ & PCP & Pd-alumina and hydrogen & $\begin{array}{l}\text { Hydrodechlorination and } \\
\text { dearomatization of ring. } \\
\text { Only product detected was } \\
\text { cyclohexanone }\end{array}$ & $\begin{array}{l}\text { Reaction conducted at room tempera- } \\
\text { ture and pressure in methanol + water } \\
\qquad(1: 99)\end{array}$ \\
\hline $\begin{array}{l}\text { Monguchi et } \\
\text { al. } 2006[57]\end{array}$ & 4-chlorophenol & $\begin{array}{l}\mathrm{Pd} / \mathrm{C} \text { and hydrogen with } \\
\text { triethylamine as an additive }\end{array}$ & $\begin{array}{l}\text { Dechlorination to phenol } \\
\text { with an yield of } 92 \%\end{array}$ & $\begin{array}{l}\text { Reaction was incomplete in the ab- } \\
\text { sence of triethylamine }\end{array}$ \\
\hline $\begin{array}{l}\text { Mertens et al. } \\
\quad 2007[58]\end{array}$ & Lindane & $\begin{array}{l}\mathrm{Pd}^{0} \text { supported on the cells of } \\
\text { Shewanella oneidensis with } \\
\text { sodium formate as the elec- } \\
\text { tron donor }\end{array}$ & $\begin{array}{l}\text { Partial and complete dechlo- } \\
\text { rination. Dichlorobenzene } \\
\text { and benzene were detected as } \\
\text { end products. Complete } \\
\text { removal of } 50 \mathrm{mg} \mathrm{L}^{-1} \text { of } \\
\text { Lindane after } 24 \mathrm{~h} \text { of reac- }^{\text {tion }}\end{array}$ & $\begin{array}{l}\text { Reaction at atmospheric pressure and } \\
\qquad 28^{\circ} \mathrm{C}\end{array}$ \\
\hline
\end{tabular}




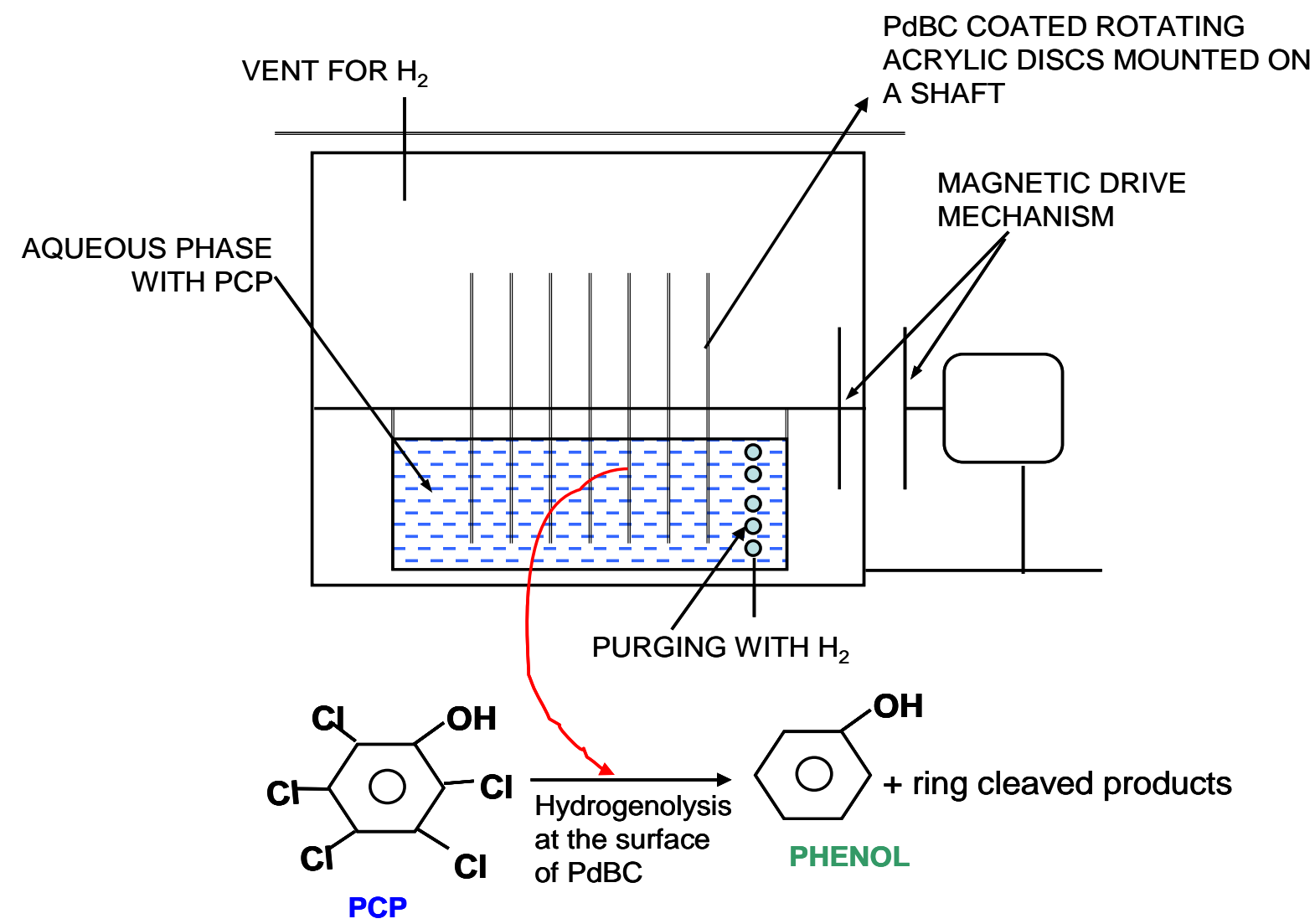

Fig. (7). Schematic diagram of rotating catalyst contact reactor (RCCR) used for treating water containing pentachlorophenol (PCP) [55]. $\mathrm{PdBC}=$ palladized bacterial cellulose .

Patel and Suresh developed a versatile reactor which employed a bio-inorganic composite catalyst [55]. A rotating catalyst contact reactor (RCCR) as shown in Fig. (7) was designed which consisted of palladized bacterial cellulose (PdBC) immobilized on circular acrylic discs for hydrodechlorination of pentachlorophenol (PCP). More than $99 \%$ of $40 \mathrm{mg} \mathrm{L}^{-1}$ PCP was dechlorinated to phenol in the presence of hydrogen in batch mode within $2 \mathrm{~h}$ of reaction (shown below) with stoichiometric release of free chloride as shown in equation 5 .

$\mathrm{C}_{6} \mathrm{OHCl}_{5}(\mathrm{PCP})+\mathrm{Pd}_{\mathrm{x}} \mathrm{H}_{\mathrm{y}}$ (palladium hydride) $\rightarrow \mathrm{C}_{6} \mathrm{H}_{6} \mathrm{O}$ $($ phenol $)+$ ring cleavage products $(?)+\mathrm{xPd}^{\circ}+5 \mathrm{HCl}$

Approximately $12 \mathrm{~L}$ and $11 \mathrm{~L}^{\circ} 40 \mathrm{mg} \mathrm{L}^{-1} \mathrm{PCP}$ (pH 6.5) could be treated in RCCR with $99 \%$ and $80 \%$ efficiencies in batch and continuous flow modes, respectively without any appreciable loss of the catalytic activity. These results suggested reusability of palladized bacterial cellulose which in turn is expected to substantially reduce the cost of treatment process. Thus RCCR seems to have high potential for treatment of ground water contaminated with chlorinated organic compounds. RCCR is simple and flexible with respect to: a) immobilization of bacterial cellulose onto rotating discs and b) in-situ reduction and immobilization of palladium onto bacterial cellulose and c) operation in batch or continuous flow mode. Scanning electron microscopy, energy dispersive $\mathrm{X}$-ray spectroscopy and $\mathrm{x}$-ray diffraction analyses suggested the irreversible deposition of nano-sized (average diameter of in the range of 100 to $150 \mathrm{~nm})$ palladium $\left(\mathrm{Pd}^{\circ}\right)$ particles on the bacterial cellulose fibrils [55]. Quantitative energy dispersive spectroscopic (EDS) analyses further indicated that the element, palladium constituted $\sim 23 \%$ of the total dry weight of PdBC. Dried palladized bacterial cellulose has been used as a material for electrodes in a fuel cell [61]. However, its application as a hydrodechlorination catalyst in a reactor operating under room temperature and atmospheric pressure has not been reported until recently.

\section{CONCLUDING REMARKS}

Zero-valent metals such as iron, zinc and magnesium have been extensively used for dechlorination reactions. The most important factors that govern the rate of reaction are $\mathrm{pH}$ of the reaction phase, precipitation of metal hydroxides and passivation of metal, surface area of the metal and hydrophobicity which encourages sorption of organics to the metal surfaces. Retrospection of the literature on the catalytic reductive degradation of various types of pollutants by bimetallic systems and immobilized catalysts illustrates that immobilization of the catalysts such as palladium onto suitable supports would prove to be a very cost-effective and efficient treatment method due to enhancement in their reusability. The support used for the immobilization of palladium should be chosen with care. The important factors to be taken into consideration are the simplicity of the immobilization process, the stability and reusability of the catalyst, prevention of damage to the support during the remediation process and application for reactor design to treat large volumes of contaminated water. 


\section{REFERENCES}

[1] L. J. Matheson, and P. G. Tratnyek, "Reductive dehalogenation of chlorinated methanes by iron metal", Environ. Sci. Technol., vol. 28, pp. 2045-2053, November 1994.

[2] G. R. Eykholt, and D. T. Davenport, "Dechlorination of the chloroacetanilide herbicides Alachlor and Metolachlor by iron metal", Environ. Sci. Technol., vol. 32, pp. 1482-1487, May 1998.

[3] Y. Ukisu, and T. Miyadera, "Dechlorination of hexachlorocyclohexanes with alkaline 2-propanol and palladium catalyst", J. Hazard Mater., vol. A122, pp. 1-6, June 2005.

[4] G. D. Sayles, G. You, M. Wang, and M. J. Kupferle, "DDT, DDD, and DDE dechlorination by zero-valent iron", Environ. Sci. Technol., vol. 31, pp. 3448-3454, December 1997.

[5] C. Schuth, and M. Reinhard, "Hydrodechlorination and hydrogenation of aromatic compounds over palladium on alumina in hydrogen-saturated water", Appl. Catal. B, vol. 18, pp. 215-221, October 1998.

[6] W.A. Arnold, W. P. Ball, and L. Roberts, "Polychlorinated ethane reaction with zero-valent zinc: pathways and rate control", J. Contam. Hydrol., vol. 40, pp. 183-200, December 1999.

[7] A. Volpe, A. Lopez, G. Mascolo, and A. Detomaso, "Chlorinated herbicide (triallate) dehalogenation by iron powder", Chemosphere, vol. 57, pp. 579-586, November 2004.

[8] W. S. Orth, and R. W. Gillham, "Dechlorination of trichloroethene in aqueous solution using Fe", Environ. Sci. Technol., vol. 30, pp. 66-71, December 1996.

[9] T. Mori, J. Kubo, and Y. Morikawa, "Hydrodechlorination of 1,1,1-trichloroethane over silica-supported palladium catalyst", Appl. Catal., A, vol. 271, pp. 69-76, September 2004.

[10] C. Schlimm, and E. Heitz, "Development of a wastewater treatment process: Reductive dehalogenation of chlorinated hydrocarbons by metals", Environ. Prog., vol. 15, pp. 38-47, August 1996.

[11] J. P. Fennelly, and A. L. Roberts, "Reaction of 1,1,1trichloroethane with zero-valent metals and bimetallic reductants", Environ. Sci. Technol., vol.32, pp. 1980-1988, July 1998.

[12] J. Dries, L. Bastiaens, D. Springael, S. Kuypers, S. N. Agathos, and L. Diels, "Effect of humic acids on heavy metal removal by zerovalent iron in batch and continuous flow column systems", Water Res., vol. 39, pp. 3531-3540, September 2005.

[13] K. J. Cantrell, D. I. Kaplan, and T. W. Wietsma, "Zero-valent iron for the in situ remediation of selected metals in groundwater", $J$. Hazard Mater., vol. 42, pp. 201-212, July 1995.

[14] T. Lee, Y. Lim, H. Lee, and J. W. Park, "Use of waste iron metal for removal of $\mathrm{Cr}$ (VI) from water", Chemosphere, vol. 53, pp. 479-485, November 2003

[15] M. Hou, F. Li, X. Liu, X. Wang, and H. Wan, "The effect of substituent groups on the reductive degradation of azo dyes by zerovalent iron", J. Hazard Mater., vol. 145, pp. 305-314, June 2007.

[16] S. Nam, and P. G. Tratnyek, "Reduction of azo dyes with zerovalent iron", Water Res., vol. 34, pp. 1837-1845, April 2000.

[17] J. Cao, L. Wei, Q. Huang, L.Wang, and S. Hang, "Reducing degradation of azo dye by zero-valent iron in aqueous solution", Chemosphere, vol. 38, pp. 565-571, February 1999.

[18] L. S. Hundal, J. Singh, E. L. Bier, P. J. Shea, S. D. Comfort, and W. L. Powers, "Removal of TNT and RDX from water and soil using iron metal", Environ. Pollut., vol. 97, pp. 57-64, No. 1, 1997.

[19] M. D. Engelmann, J. G. Doyle, and I. F. Cheng, "The complete dechlorination of DDT by $\mathrm{Mg}^{0} / \mathrm{Pd}$ bimetallic particles", Chemosphere, vol. 43, pp. 195-198, April 2001

[20] S. R. Kanel, B. Manning, L. Charlet, and H. Choi, "Removal of arsenic (III) from groundwater by nanoscale zero-valent iron", Environ. Sci. Technol., vol. 39, pp.1291-1298, March 2005.

[21] S. M. Ponder, J. G. Darab, and T. E. Mallouk, "Remediation of Cr (VI) and $\mathrm{Pb}$ (II) aqueous solutions using supported, nanoscale zerovalent iron", Environ. Sci. Technol., vol. 34, pp. 2564-2569, June 2000 .

[22] S. Choe, S. Lee, Y. Chang, K. Hwang, and J. Kim, "Rapid reductive destruction of hazardous organic compounds by nanoscale $\mathrm{Fe}^{0}$,, Chemosphere, vol. 42, pp. 367-372, February 2001.

[23] H. Y. Shu, M. C. Chang, H. H. Yu, and W. H. Chen, "Reduction of an azo dye Acid Red Black 24 solution using synthesized nanoscale zero-valent iron particles", J. Colloid Interface Sci., vol. 314: pp. 89-97, October 2007.

[24] R. G. Vidic, and R. G. Pohland, "Treatment walls", Technol. Evaluat. Report (TE-96-01), pp. 1-38, 1996.
C. Grittini, M. Malcomson, Q. Fernando, and N. Korte, "Rapid dechlorination of polychlorinated biphenyls on the surface of a Pd/Fe bimetallic system", Environ. Sci. Technol., vol. 29, pp. 28983000, November 1995.

[26] R. A. Doong, and S. C. Wu, "Reductive dechlorination of chlorinated hydrocarbons in aqueous solutions containing ferrous and sulfide ions", Chemosphere, vol. 24, pp. 1063-1075, April 1992.

[27] S.F. Cheng, and S. C. Wu, "The enhancement methods for the degradation of TCE by zero-valent metals", Chemosphere, vol. 41, pp. 1263-1270, October 2000.

[28] S. K. Gautam, and S. Suresh, "Dechlorination of DDT, DDE, and DDD in soil (slurry) phase using magnesium/palladium system", $J$. Colloid Interface Sci., vol. 304, pp. 144-151, December 2006.

[29] U. D. Patel, and S. Suresh, "Dechlorination of chlorophenols using magnesium-silver bimetallic system", J. Colloid Interface Sci., vol. 299, pp. 249-259, July 2006.

[30] U. D. Patel, and S. Suresh, "Dechlorination of chlorophenols using magnesium-palladium bimetallic system", J. Hazard Mater., vol. 147, pp. 431-438, August 2007.

[31] M. D. Engelmann, R. Hutcheson, K. Henschied, R. Neal, and I. F. Cheng, "Simultaneous determination of total polychlorinated biphenyl and dichloro diphenyl trichloroethane (DDT) by dechlorination with $\mathrm{Fe} / \mathrm{Pd}$ and $\mathrm{Mg} / \mathrm{Pd}$ bimetallic particles and flame ionization detection gas chromatography", Microchem. J., vol. 74, pp.1925, February 2003.

[32] C. B. Wang, and W. X. Zhang, "Synthesizing nanoscale iron particles for rapid and complete dechlorination of TCE and PCBs", Environ. Sci. Technol., vol. 31, pp. 2154-2156, July 1997.

[33] L. Liang, N. Korte, J. D. Goodlaxson, J. Clausen, Q. Fernando, and R. Muftikian, "Byproduct formation during the reduction of TCE by zero-valent iron and palladized iron", Ground Water Monit. Rem., vol. 17, pp. 122-127, February 1997.

[34] I. F. Cheng, Q. Fernando, and N. Korte, "Electrochemical dechlorination of 4-chlorophenol to phenol", Environ. Sci. Technol., vol. 31, pp.1074-1078, April 1997

[35] S. K. Gautam, and S. Suresh, "Studies on dechlorination of DDT [1, 1, 1-trichloro-2, 2-bis (4-chlorophenyl) ethane] using magnesium/palladium bimetallic system", J. Hazard Mater., vol. 139, pp.146-153, January 2007.

[36] Y. H. Kim, and E. R. Carraway, "Dechlorination of pentachlorophenol by zero valent iron and modified zero-valent irons", Environ. Sci. Technol., vol. 34, pp. 2014-2017, May 2000.

[37] J. Morales, R. Hutcheson, C. Noradoun, and I. F. Cheng, "Hydrogenation of phenol by the $\mathrm{Pd} / \mathrm{Mg}$ and $\mathrm{Pd} / \mathrm{Fe}$ bimetallic system under mild reaction conditions", Ind. Eng. Chem. Res., vol. 41, pp. 3071-3074, June 2002.

[38] S. S. Zinovyev, N. A. Shinkova, A. Perosa, and P. Tundo, "Dechlorination of lindane in the multiphase catalytic reduction system with Pd/C, Pt/C and Raney-Ni”, Appl. Catal., B, vol. 47, pp. 27-36, January 2004.

[39] R. Muftikian, Q. Fernando, and N. Korte, "A method for the rapid dechlorination of low molecular weight chlorinated hydrocarbons in water", Water Res., vol. 29, pp. 2434-2439, October 1995.

[40] J. Feng, and T. Lim, "Pathways and kinetics of carbon tetrachloride and chloroform reductions by nano-scale $\mathrm{Fe}$ and $\mathrm{Fe} / \mathrm{Ni}$ particles: comparison with commercial micro-scale $\mathrm{Fe}$ and $\mathrm{Zn}$ ", Chemosphere, vol. 59, pp. 1267-1277, June 2005.

[41] N. E. Korte, J. L. Zutman, R. M. Schlosser, L. Liang, B. Gu, and Q. Fernando, "Field application of palladized iron for the dechlorination of trichloroethene", Waste Manage. (Oxford), vol. 20, pp. 687694, December 2000.

[42] R. Patel, and S. Suresh, "Decolourization of azo dyes using magnesium-palladium system", J. Hazard Mater., vol. 137, pp. 1729 1741, October 2006.

[43] F. J. Urbano, and J. M. Marinas, "Hydrogenolysis of organohalogen compounds over palladium supported catalysts", J. Mol. Catal., A, vol. 173, pp. 329-345, September 2001

[44] N. V. Kramareva, A. Y. Stakheev, O. P. Tkachenko, K. V. Klementiev, W. Grünert, E. D. Finashina, and L. M. Kustov, "Heterogenized palladium chitosan complexes as potential catalysts in oxidation reactions: study of the structure", J. Mol. Catal., A, vol. 209 pp. 97-106, February 2004.

[45] E. A. Cagnola, M. E. Quiroga, D. A. Liprandi, and P. C. L'Argentiere, "Immobilized $\mathrm{Rh}, \mathrm{Ru}, \mathrm{Pd}$ and $\mathrm{Ni}$ complexes as catalysts in the hydrogenation of cyclohexene", Appl. Catal., A, vol. 274, pp. 205-212, October 2004 
[46] C. G. Schreier, and M. Reinhard, "Catalytic hydrodehalogenation of chlorinated ethylenes using palladium and hydrogen for the treatment of contaminated water", Chemosphere, vol. 31, pp. 34753487, September 1995.

[47] J. B. Hoke, G. A. Gramiccloni, and E. N. Balko, "Catalytic hydrodechlorination of chlorophenols", Appl. Catal., B, vol. 1, pp. 285-296, December 1992.

[48] F. Zhang, J. Chen, H. Zhang, Y. Ni, and X. Liang, "The study on the dechlorination of OCDD with $\mathrm{Pd} / \mathrm{C}$ catalyst in ethanol-water solution under mild conditions", Chemosphere, vol. 68, pp. 17161722, August 2007.

[49] F. Zhang, J. Chen, H. Zhang, Y. Ni, Q. Zang, and X. Liang, "Dechlorination of dioxins with $\mathrm{Pd} / \mathrm{C}$ in ethanol-water solution under mild conditions", Sep. Purif. Technol., vol. 59, pp.164-168, February 2008.

[50] Y. Ukisu, S. Kameoka, and T. Miyadera, "Catalytic dechlorination of aromatic chlorides with noble-metal catalysts under mild conditions: approach to practical use", Appl. Catal., B, vol. 27, pp. 97104, July 2000.

[51] G. Yuan, and M. A. Keane, "Liquid phase hydrodechlorination of chlorophenols over $\mathrm{Pd} / \mathrm{C}$ and $\mathrm{Pd} / \mathrm{Al}_{2} \mathrm{O}_{3}$ : a consideration of $\mathrm{HCl} /$ catalyst interactions and solution $\mathrm{pH}$ effects", Appl. Catal., B, vol. 52, pp. 301-314, October 2004.

[52] Y. Ukisu, and T. Miyadera, "Hydrogen-transfer hydrodehalogenation of aromatic halides with alcohols in the presence of noble metal catalysts", J. Mol. Catal., A, vol. 125, pp. 135-142, November 1997.

[53] Y. Ukisu, and T. Miyadera, (2003), "Hydrogen-transfer hydrodechlorination of polychlorinated dibenzo- $p$-dioxins and dibenzofurans catalyzed by supported palladium catalysts", Appl. Catal., $B$, vol. 40, pp. 141-149, January 2003.

[54] M. A. Aramendıa, R. Burch, I. M. Garc, A. Marinas, J. M. Marinas, B. W. L. Southward, and F. J. Urbano, "The effect of the addition of sodium compounds in the liquid-phase hydrodechlorination of chlorobenzene over palladium catalysts", Appl. Catal., B, vol. 31, pp. 163-171, May 2001.

[55] U. D. Patel, and S. Suresh, "Complete dechlorination of pentachlorophenol using palladized bacterial cellulose in a rotating catalyst contact reactor", J. Colloid Interface Sci., vol. 319, pp. 462-469, March 2008.

[56] H. M. Roy, C. M. Wai, T. Yuan, J-K. Kim, and W.D. Marshall, "Catalytic hydrodechlorination of chlorophenols in aqueous solution under mild conditions", Appl. Catal., A, vol. 271, pp. 137-143, September 2004.

[57] Y. Monguchi, A. Kume, K. Hattori, T. Maegawa, and H. Sajiki, (2006). "Pd/C-Et ${ }_{3} \mathrm{~N}$-mediated catalytic hydrodechlorination of aromatic chlorides under mild conditions", Tetrahedron, vol. 62, pp. 7926-7933, August 2006.

[58] B. Mertens, C. Blothe, K. Windey, W. D. Windt, and W. Verstraete, (2007). "Biocatalytic dechlorination of lindane by nanoscale particles of $\operatorname{Pd}(0)$ deposited on Shewanella oneidensis", Chemosphere, vol. 66, pp. 99 -105, January 2007.

[59] G. Yuan, and M. A. Keane, "Catalyst deactivation during the liquid phase hydrodechlorination of 2,4-dichlorophenol over supported Pd: influence of the support", Catal. Today, vol. 88, pp. 27-36, December 2003.

[60] M. A. Aramendia, V. Borau, I. M. Garcia, C. Jimenez, F. Lafont, A. Marinas, J. M. Marinas, and F. J. Urbano, "Influence of the reaction conditions and catalytic properties on the liquid-phase hydrodechlorination of chlorobenzene over palladium-supported catalysts: activity and deactivation", J. Catal., vol. 187, pp. 392-399, October 1999.

[61] B. R. Evans, H. M. O’Neill, V. P. Malyvanh, I.. Lee, and J. Woodward, "Palladium-bacterial cellulose membranes for fuel cells", Biosens. Bioelectron., vol. 18, pp. 917-923, July 2003.

(C) Sumathi Suresh; Licensee Bentham Open.

This is an open access article licensed under the terms of the Creative Commons Attribution Non-Commercial License (http://creativecommons.org/licenses/by$\mathrm{nc} / 3.0 /$ ) which permits unrestricted, non-commercial use, distribution and reproduction in any medium, provided the work is properly cited. 